\title{
THE ENHANCEMENTS' SKILL OF WRITING POETRY BY PICTURE AND PICTURE DESIGN OF TREE GRADE STUDENTS AT MANGKUYUDAN NO.02 ELEMENTARY SCHOOL SURAKARTA IN THE ACADEMIC YEAR OF 2017/2018
}

\section{Bekti Lestari, Retno Winarni, Suharno}

Universitas Sebelas Maret

winarniuns@yahoo.com

Article History

accepted 09/07/2018

approved 01/08/2018

published 17/09/2018

\section{Keywords}

learning cell strategy, posing question, social studies

\begin{abstract}
The purpose of this research was to improve the skill of writing poetry by applied picture and picture design for tree grade students in SDN Mangkuyudan No.02 Surakarta on academic year of 2017/2018. It is caused by learning to write poetry that has not done well so class tree grade student have difficulty when asked to write a poem Therefore, the necessary learning strategies and instructional media fun and appropriate. The data collected by interview, observation, test, and documentation techniques. The data validity test were using content validity, triangulation of resource, and triangulation of technique. The result of this research shows the improvement of skill of writing poetry values from pre-action, cycle I until cycle II.
\end{abstract}

Social, Humanities, and Education Studies (SHEs): Conference Series https://jurnal.uns.ac.id/shes 


\section{PENDAHULUAN}

Menulis berarti mengekspreiskan secara tertulis gagasan, ide, pendapat, atau pikiran dan perasaan menurut Djago Tarigan dalam Elina Syarif, Zulkarnaini, Sumarno (2009:5).Keterampilan (skill) merupakan suatu yang dimiliki oleh individu untuk melakukan tugas yang dibebankan (Sanjaya, 2008:7). Menurut Gutiérrez, dkk (2015: 49), “... writing skill is a cognitive process (White \& Arndt, 1991) that involves the activation of a series of non-linear mental operations (Hedge, 2005) to organize and arrange the ideas on a piece of paper". Pendapat tersebut dapat diartikan bahwa keterampilan menulis merupakan proses kognitif yang melibatkan pengaktifan serangkaian operasi mental non-linear untuk mengatur gagasan di selembar kertas.

Nofal dalam International Journal of Bussinesand Social Science menyatakan bahwa: "Sentence structure and phrase structure in the poetic language is different from those of any literaly genre and is similar to those of spoken code. Poets permit themselves considerable freedom in word order for certain purposes, e.g. emphasis, front fokus, end fokus, end weigth or rhyme ... etc, for syntax is similar to that of the spoken language" (2011: 62). Pendapat tersebut dapat diartikan bahwa struktur kalimat dalam puisi memiliki perbedaan dengan karya sastra yang lain serta merupakan karya yang bebas dituangkan oleh penyairnya dengan variasi kata yang diinginkan. Puisi adalah bahasa untuk menyampaikan ide dan gagasan menggunakan bahasa yang indah. Menurut Waluyo (2002:1) mengatakan puisi adalah karya sastra dengan bahasa yang dipadatkan, dipersingkat, dan diberi irama dengan bunyi yang padu dan pemilihan kata-kata kias (imajinatif). Sedangkan menurut Wiyanto (2006:48) seseorang bisa saja terampil menulis puisi karenaa giat belajar dan berlatih karena sesungguhnya menulis puisi merupakan sebuah keterampilan.

Kondisi awal keterampilan menulis siswa kelas III SDN Mangkuyudan no 02 yang masih sangat rendah diperkuat dengan hasil pretest. Pretest dilakukan berdasarkan kisi-kisi soal dan soal tes keterampilan menulis pada pratindakan. Penilaiannya berdasarkan pedoman penilaian tes unjuk kerja keterampilan menulis. Dalam melaksanakan pratindakan nilai rata-rata keterampilan menulis puisi hanya sebesar 69,63 pada tingkat ketuntasan dari hasil belajar siswa pada pelaksanaan pratindakan sebanyak 5 siswa atau 18,5\% telah mencapai $\geq 75$ (KKM). Berdasarkan hasil tes pra-tindakan tersebut perlu dilakukan upaya peningkatan keterampilan menulis puisi. Usaha peningkatan keterampilan menulis puisi dapat dilakukan dengan menggunakan model picture and picture. Model pembelajaran tersebut membuat peserta didik menulis sesuai dengan tahapan menulis yang sistematis, sehingga guru bisa memberikan bimbingan secara langsung pada setiap tahap.

Model pembelajaran kooperatif picture and picture adalah model pembelajaran yang ditekankan pada gambar yang diurutkan menjadi urutan yang logis, mengembangkan interaksi antar siswa yang saling asah, silih asih, dan asuh (Zaenal, 2012 : 14). Sedangkan , model pembelajaran picture and picture adalah model pembelajaran yang dikontruksi dengan rangkaian gambar secara logis (Miftahul Huda, 2010 : 176 ). Lain lagi menurut Suprijono (2010: 110 ) metode picture and picture adalah metode pembelajaran yang menggunakan gambar atau diururtkan menjadi urutan logis. Sedangkan menurut Taniredja ( 2013 : 55 ) bahwa pembelajaran kooperatif merupakan system pengajaran yang memberi keempatan pada anak didik untuk bekerja sama dengan sesama siswa dalam tugas-tugas yang berstruktur, berkelomok, sehingga terjadinya interaksi secara terbuka dan hubungan yang bersifat 
interdependensi efektif di antara anggota kelompok. Jadi, model picture and picture merupakan model pembelajaran yang penggunaannya berupa gambar seri maupun tunggal dengan tujuan agar siswa lebih mudah dalam memahami konsep baik individu ataupun dalam kelompok.

Berdasarkan latar belakang masalah tersebut, rendahnya keterampilan menulis puisi pada siswa kelas III SD Negeri Mangkuyudan No.02 Surakarta tahun ajaran 2017/2018 maka penulis mengambil penelitian dengan judul "penggunaan model picture and picture untuk meningkatkan keterampilan menulis puisi pada siswa kelas III SD N di surakarta tahun ajaran 2017/2018".

\section{METODE}

Bentuk penelitian yang digunakan dalam penelitian ini yaitu penelitian tindakan kelas (Classroom action research). Menurut Suharsimi Arikunto, dkk (2010: 3) menyatakan bahwa, "Penelitian tindakan kelas merupakan suatu pencermatan terhadap kegiatan belajar berupa sebuah tindakan, yang sengaja dimunculkan dan terjadi dalam sebuah kelas secara bersama".Penelitian ini dilakukan di SD Negeri Mangkuyudan No.02 Surakarta tahun ajaran 2017/2018 pada bulan Januari-Juni 2018. Subjek penelitian ini adalah siswa kelas III yang berjumlah 27 siswa, terdiri dari 12 siswa laki-laki dan 15 siswa perempuan. Semua siswa di kelas III memiliki kondisi fisik dan kejiwaan yang sehat, dengan kata lain tidak ada siswa yang cacat.

Teknik pengumpulan data yaitu melalui observasi, wawancara dan doku-mentasi. Uji validitas data dilakukan dengan triangulasi teknik dan triangulasi sumber data. Prosedur penelitian menurut Suharsimi Arikunto, (2011: 17-20), penelitian tindakan kelas dimulai dengan siklus pertama yang terdiri dari empat kegiatan yakni menyusun perencanaan (planning), tindakan (acting), pengamatan (observing), dan refleksi.

Adapun hal-hal yang dilakukan dalam perencanaan adalah sebagai berikut: (1) Mengkaji kurikulum untuk mengetahui standar kompetensi dan kompetensi dasar yang akan disampaikan pada siswa serta yang harus dicapai oleh siswa dalam pembelajaran; (2) Menyusun Rencana Pelaksanaan Pembelajaran (RPP); (3) Menyiapkan sarana dan prasarana selama proses pembelajaran dengan penerapan model picture and picture; (4) Menyusun panduan observasi kinerja guru dalam perencanaan pembelajaran; (5) Menyusun panduan observasi kinerja guru dalam pelaksanaan pembelajaran.

Indikator kinerja penelitian ini adalah peningkatan keterampilan menulis puisi siswa dalam mata pelajaran Bahasa Indonesia dengan ketercapaian target $80 \%$ jumlah siswa di kelas. Peningkatan keterampilan menulis puisi yang diukur malalui tes yang memiliki penilaian dari aspek: 1) Penyampaian gagasan; 2) Pemilihan kata; 3) Koherensi atau ketepatan; 4) Ketepatan judul dengan isi; 5) Rima dengan irama (Rukayah $(2012,123)$ ).

\section{HASIL DAN PEMBAHASAN}

Penelitian ini dilakukan selama 2 siklus. Setiap siklus terdiri dari 2 kali pertemuan dengan alokasi waktu $2 \times 35$ menit dan $2 \times 35$ menit. Materi yang dipelajari pada penelitian ini adalah pengertian puisi, unsur-unsur puisi dan langkah-langkah menulis puisi.

Analisis data hasil observasi kinerja guru pada kegiatan siklus I dan siklus II dapat dikatakan mengalami peningkatan yang signi-fikan dibandingkan pada kegiatan 
pra-siklus. Skor pada kegiatan pra-siklus sejumlah 1,67 ( kurang baik) mengalami peningkatan skor dengan mendapatkan skor sejumlah 3,00 (baik) pada siklus I dan 3,69 (baik) pada siklus II seperti yang ditampilkan pada Gambar 1.

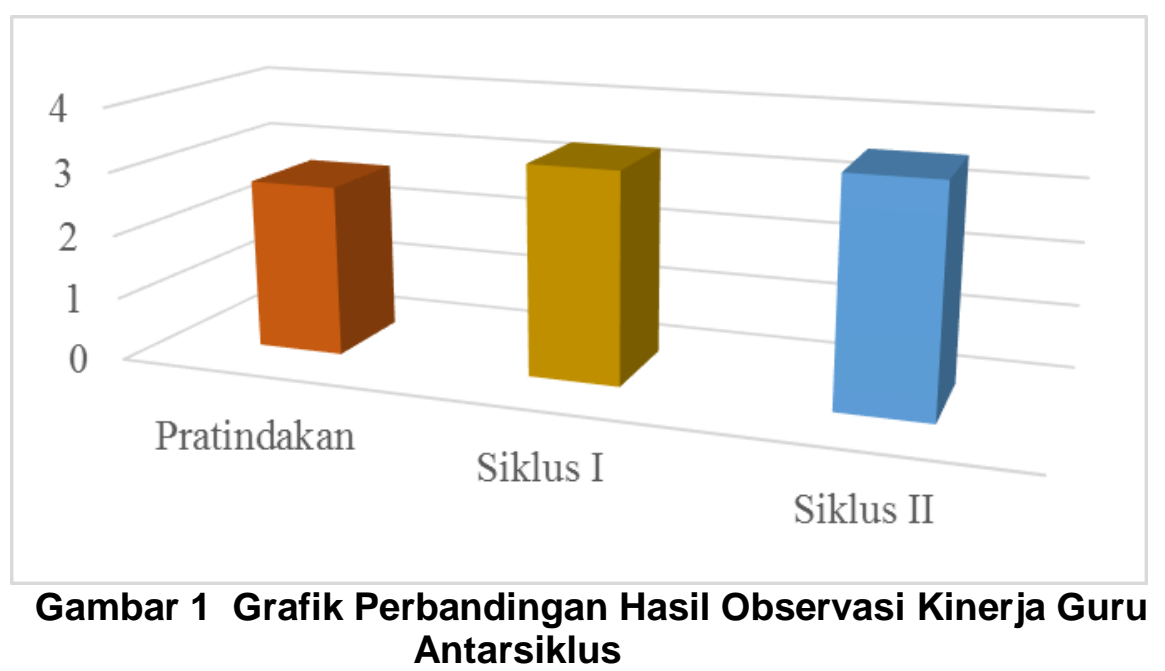

Pada kegiatan pra-siklus, guru sudah baik dalam mengajar namun masih ditemukan kekurangan dalam pemanfaatan media dan peserta didik kurang antusias dalam pembelajaran, sedangkan setelah dilakukan tindakan dengan menerapkan model picture and picture pada siklus I dan siklus II kinerja guru mendapatkan skor yang lebih baik dibandingkan pada pra-siklus. Peserta didik menunjukkan antusias yang lebih baik ketika kegiatan pembelajaran berlangsung dengan menerapkan model pictue and picture. Perbandingan aktivitas peserta didik dapat dilihat pada Gambar 2.

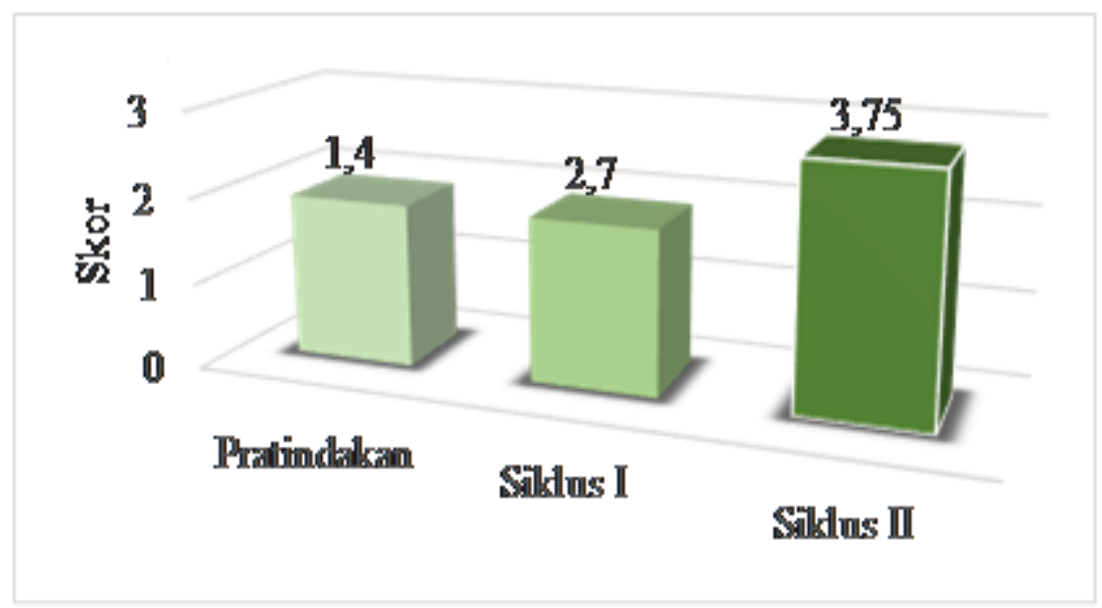

\section{Gambar 2 Grafik Perbandingan Hasil Observasi Aktivitas Siswa Antarsiklus}

Berdasarkan hasil pengamatan, diketahui dari gambar 2 bahwa aktivitas siswa mengalami peningkatan dari pratindakan ke siklus I, dan mengalami peningkatan pada siklus II. Pada pratindakan, aktivitas siswa dalam kategori cukup baik dengan skor 1,4. Pada siklus I belum mengalami peningkatan dengan perolehan skor 2,7 dikategori cukup baik. Aktivitas peserta didik mengalami peningkatan pada siklus II dengan skor 3,75 dan mendapat kategori sangat baik. Dengan demikian, ada peningkatan aktivitas peserta didik dari kondisi awal yang cukup baik menjadi sangat baik di akhir tindakan. 
Peningkatan juga terjadi terhadap nilai tes keterampilan menulis puisi peserta didik. Nilai rata-rata kelas, ketuntasan klasikal, nilai tertinggi dan nilai terendah mengalami peningkatan dari kegiatan pra-siklus ke siklus I dan siklus II. Perbandingan Hasil Keterampilan Menulis Puisi Antarsiklus dapat dilihat pada Gambar 3.

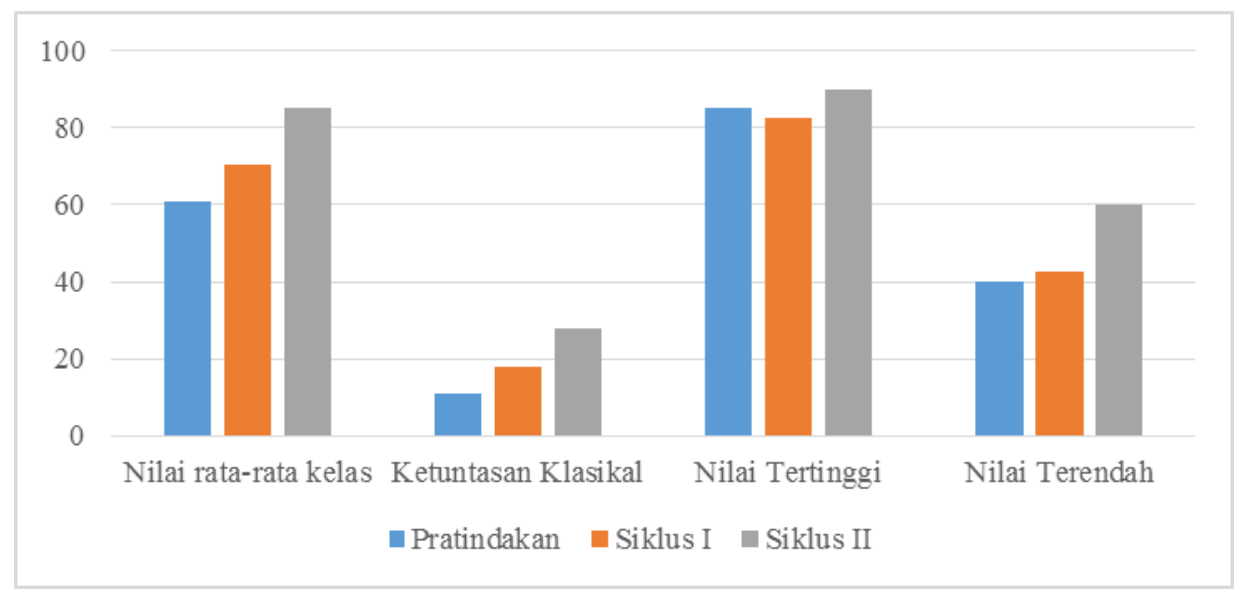

Hasil penelitian menunjukkan adanya peningkatan pada setiap tindakan mulai dari pratindakan, siklus I, dan siklus II. Peningkatan terjadi pada nilai rata-rata kelas, persentase ketuntasan, kinerja guru, dan aktivitas siswa. Penelitian Tindakan Kelas ini dilaksanakan dalam dua siklus dan menerapkan model picture and picture untuk meningkatkan keterampilan menulis puisi.

Kondisi awal sebelum diterapkannya model picture and picture, keterampilan menulis puisi peserta didik masih rendah yang dapat dilihat dari nilai uji pratindakan dan juga dari wawancara dengan guru sebelum tindakan yang menunjukkan bahwa peserta didik tidak terlalu menyukai materi menulis pada pelajaran Bahasa Indonesia sehingga mereka kurang antusias dan cenderung malas. Dengan kondisi tersebut, persentase ketuntasan klasikal pada pratindakan hanya sebesar 18,5 \% (5 anak), sedangkan persentase peserta didik yang mendapatkan nilai dibawah KKM (75) sebesar $81,57 \%$ (22 anak). Pembelajaran menulis sebelum dilaksanakan tindakan belum optimal karena strategi atau media pembelajaran yang digunakan guru kurang inovatif, salah satunya dengan mendikte. Siswa menjadi kurang kreatif dalam menuangkan ide yang dia punya. Melalui wawancara dengan peserta didik diketahui juga bahwa peserta didik masih kesulitan dalam memilih kata yang akan mereka gunakan dalam pembelajaran menulis. Hal tersebut dapat dibuktikan dari hasil kinerja guru dengan skor (kategori baik) dan hasil aktivitas siswa dengan skor 1,67 (kategori cukup baik).

Pelaksanaan yang dilakukan pada siklus I terjadi peningkatan persentase ketuntasan klasikal. Persentase ketuntasan klasikal pada pratindakan diperoleh sebesar 18,5\% (5 peserta didik) dan meningkat pada siklus I menjadi 33,33\% (18 peserta didik). Peserta didik mulai tertarik terhadap pembelajaran menulis puisi dengan diterapkannya model picture and picture ketika pembelajaran. Hal ini terjadi karena peserta didik terfasilitasi oleh guru berupa bimbingan dan arahan yang selalu diberikan disertai umpan balik sehingga dapat segera dilakukan perbaikan. Peserta didik di dibimbing dan diarahkan oleh guru untuk menulis sesuai dengan langkah-langkah menulis yang baik dengan bantuan media gambar. Bimbingan diberikan secara berkelanjutan sehingga kebutuhan peserta didik terhadap kemampuan menulis dapat terpantau dengan baik dan dapat segera diperbaiki apabila mengalami kekurangan. 
Hasil keterampilan menulis puisi peserta didik dipantau oleh guru melalui draf awal yang dibuat peserta didik pada pertemuan pertama. Setelah draf awal diperiksa oleh guru, pada pertemuan kedua tulisan siswa tersebut direvisi dengan menggunakan bantuan lembar kritik dan saran yang dilakukan oleh kelompok berpasangannya. Pada siklus I peserta didik masih sedikit kesulitan mengisi lembar kritik dan saran untuk merevisi tulisan teman. Guru terus membimbing peserta didik dalam penggunaan lembar kritik dan saran tersebut. Dengan demikian, peserta didik dapat terfasilitasi sehingga siswa dapat meningkatkan keterampilan menulis puisi yang dapat dilihat dengan nilai tes menulis puisi peserta didik. Pada siklus I kinerja guru meningkat menjadi 3 (kategori baik) dan aktivitas peserta didik belum meningkat, masih pada skor 1,4 (kategori cukup baik).

Pelaksanaan pada siklus II guru meningkatkan intenstas bimbingan setiap tahapan menulis. Peserta didik sudah memahami bagaimana mengisi lembar kritik dan saran sehingga dapat membimbing siswa untuk merevisi hasil tulisan awalnya. Penerapan model picture and picture mampu membimbing peserta didik dalam menulis secara bertahap dan baik. Hal tersebut diperkuat dengan hasil wawancara dengan guru kelas bahwa penerapan model picture and picture sudah sesuai dengan karakteristik siswa. Guru kelas III berpendapat bahwa model picture and picture merupakan strategi yang efektif dan tepat untuk meningkatkan keterampilan menulis puisi karena peserta didik selalu dibimbing dalam setiap tahapan menulis, dan peserta didik menjadi tahu bagaimana urutan menulis yang baik.

Hasil observasi pada siklus II, kinerja guru meningkat menjadi 3,69 (kategori baik), sedangkan untuk aktivitas peserta didik meningkat menjadi 3,75 (kategori baik). Masih terdapat 9 peserta didik yang belum tuntas atau setara dengan 33,33\%. Hal tersebut dikarenakan peserta didik masih kesulitan memilih kata yang akan mereka gunakan untuk menulis puisi. Selain itu, susunan kata per baris pada puisi juga belum saling berhubungan maknanya. Persentase klasikal ketuntasan siklus II sudah mencapai indikator kinerja penelitian yang ditetapkan sebesar $80 \%$ sehingga penelitian tindakan kelas ini dihentikan pada siklus II, karena telah mencapai indikator kinerja penelitian.

Penelitian tindakan kelas ini telah dilaksanakan sesuai dengan langkah-langkah penerapan model picture and picture dalam pembelajaran menulis puisi, sehingga dapat menjawab rumusan masalah yang telah dikemukakan oleh peneliti. Dengan demikian, dapat disimpulkan bahwa penerapan model picture and picture dapat meningkatkan keterampilan menulis puisi siswa kelas III SDN Mangkuyudan No.02 Surakarta tahun ajaran 2017/2018.

\section{SIMPULAN}

Berdasarkan pada hasil penelitian tindakan kelas yang sudah dilaksanakan selama dua siklus untuk pelajaran Bahasa Indonesia materi menulis puisi dengan menerapkan model picture and picture pada siswa kelas kelas III SDN Mangkuyudan No.02 Surakarta tahun ajaran 2017/2018, dapat ditarik kesimpulan bahwa penerapan model picture and picture dapat meningkatkan keterampilan menulis puisi siswa kelas kelas III SDN Mangkuyudan No.02 Surakarta tahun ajaran 2017/2018.

Berkaitan dengan hasil penelitian, peneliti mengajukan saran 1) bagi guru, hendaknya mempertimbangkan penggunaan model picture and picture dalam pembelajaran menulis, karena strategi ini dapat melatih peserta didik menjadi penulis yang baik dan menjadi lebih aktif ketika pembelajaran sedang berlangsung; 2) bagi sekolah, hendaknya menyediakan fasilitas yang berkontribusi dalam menerapkan 
proses belajar mengajar yang inovatif $n$; 3) peneliti yang ingin meneliti masalah yang sama dihara dapat fokus dalam hal pengkajian teori-teori yang berkaitan dengan penerapan model picture and picture.

\section{DAFTAR PUSTAKA}

Eanes, R. (1997). Content Area Literacy. Boston: Delmar Publisher.

Gutiérrez, dkk. (2015). Using Pictures Series Technique to Enhance Narrative Writing among Ninth Grade Students at Institución Educativa Simón Araujo. International Journal of English Languange Teaching. Vol. 8, No. 5

Nofal, K. H. (2011). Syntatic Aspects of Poetry: A Pragmatic Perspective. International Journal of Bussines and Social Science, Vol. 2, No. 16.

Rukayah. (2013). Pedoman Pelaksanaan Menulis dengan Pendekatan Whole Language di Sekolah Dasar. Surakarta: UNS Press.

Sillin dan Chan, Andrea. (2015). Effectiveness of the English Writing Process for Postsecondary School Students. International Journal of English Languange Education. Vol. 3, No. 1.

Prasetyo, Budi. 2007. Peningkatan pembelajaran menulis puisi dengan strategi pikir plus. (online). http:// jurnal Ipi.wordspress.com /kategory/imp/page 12/diunduh tanggal 7 februari 2012.

Waluyo, Herman J. 2003. Apresiasi Puisi Panduan untuk Pelajar dan Mahasiswa. Jakarta: Gramedia Pustaka Utama.

IGAK Wardahni, dkk (2006). Prnrlitian Tindakan Kelas. Jakrta: Universitas Terbuka

Suharsimi Arikunto. (2011). Penelitian Tindakan. Yogyakarta: Aditya Media 